\title{
Gangguan Seksual pada Akseptor Suntik Depo Medroxyprogesteron Asetat
}

\section{Sexual Disorders on Acceptors of Depo Medroxyprogesterone Acetate Contraseption}

\author{
Tarsikah Tarsikah $^{1}{ }^{凶}$, Wahyu Setyaningsih ${ }^{1}$, Yusniyah Abdilla ${ }^{1}$ \\ ${ }^{1}$ Program Studi Kebidanan, Politeknik Kesehatan Kemenkes Malang, Indonesia \\ ${ }^{\bowtie}$ Corresponding author e-mail: tarsikah08@gmail.com, Alamat: Jln. Besar Ijen 77 C Malang, Jawa Timur, Indonesia, \\ 65112
}

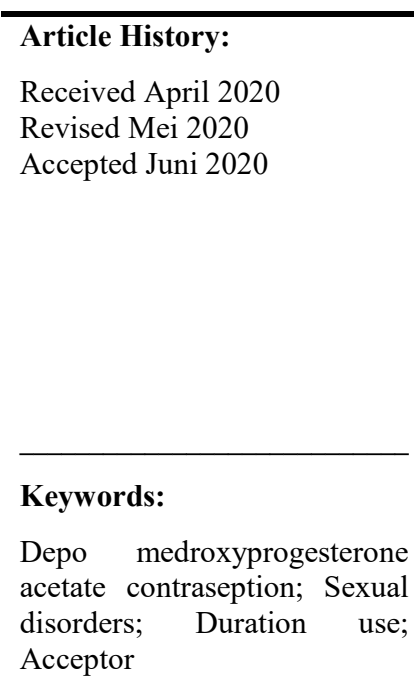

\section{Kata kunci:}

Suntik depo medroxyprogesterone; Gangguan seksual; Lama penggunaan kontrasepsi; Akseptor

\begin{abstract}
s
Background: Depo medroxyprogesterone acetat (DMPA) injection is one of the controception methods most used by women, but many of them do not know the longterm effects. The content of the progestin hormone in contraception DMPA can suppress the hormone estrogen so that the vagina becomes dry and results in sexual disorders. Purpose: To determine the duration use of depo medroxyprogesterone controception acetat use with sexual disorders. Methods: Observational analytic study with cross-sectional design. The research sample consisted of 60 DMPA acceptors selected by simple random sampling. The research variables were the duration controception use of DMPA and sexual disorders. The research instrument used the Female Sexual Function Index questionnaire. Data analysis using chi-square with a significance level of 0.05 . Results: The results showed that of 26 respondents with a duration of DMPA contraception $\geq 5$ years all $(100 \%)$ had a sexual disorder. The results of the study analysis showed that there was a relationship between the duration use of depo medroxyprogesterone injection and sexual disorders $(\mathrm{p}=0.038)$. Conclusion: The duration use of DMPA injection increases the incidence of sexual disorders in acceptors. DMPA acceptors for switching use hormonal and nonhormonal contraceptives to reduce the side effects of sexual disorders.
\end{abstract}

\section{Abstrak}

Latar Belakang: Kontrasepsi suntik Depo Medroksiprogesteron Asetat (DMPA) merupakan salah satu metode kontrasepsi yang paling banyak digunakan oleh wanita, namun banyak dari mereka tidak mengetahui efek jangka panjangnnya. Kandungan hormon progestine dalam kontrasepsi DMPA dapat menekan hormon estrogen sehingga vagina menjadi kering dan mengakibatkan gangguan seksual. Tujuan: Mengetahui hubungan lama penggunaan suntik DMPA dengan gangguan seksual. Metode: Penelitian analitik observasional dengan rancangan studi cross sectional. Sampel penelitian berjumlah 60 akseptor suntik DMPA yang dipilih secara simple random sampling. Variabel penelitian adalah lama penggunaan kontrasepsi suntik $D M P A$ dan gangguan seksual. Instrumen penelitian menggunakan kuesioner FSFI. Analisis data menggunakan chi square dengan tingkat kemaknaan 0.05. Hasil: Hasil penelitian menunjukkan dari 26 responden dengan lama penggunaan kontrasepsi Depo Medroxyprogesterone $\geq 5$ tahun semua $(100 \%)$ mengalami gangguan seksual. Hasil analisis menunjukkan ada hubungan antara lama penggunaan suntik DMPA dengan gangguan seksual $(\mathrm{p}=0.038)$. Simpulan: Lama penggunaan kontrasepsi suntik DMPA meningkatkan kejadian gangguan seksual pada akseptor. Akseptor DMPA agar switching menggunakan kontrasepsi hormonal dan bukan hormonal untuk mengurangi efek samping gangguan seksual.

Copyright (C) 2020 Jurnal Kesehatan Metro Sai Wawai All rights reserved. 


\section{Pendahuluan}

Depo Medroksiprogesteron Asetat (DMPA) merupakan kontrasepsi yang diberikan setiap 3 bulan dengan cara disuntikkan secara intramuskuler. Suntik progestin lebih efisien tetapi memiliki efek samping yang signifikan (Ozgoli, Sheikhan, Dolatian, Simbar, Bakhtyari, \& Nasiri, 2015). Pada penggunaan jangka panjang dapat mengakibatkan perubahan lipid serum, kepadatan tulang, gangguan emosi, sakit kepala, jerawat, kekeringan pada vagina dan mengakibatkan gangguan seksual. Hubungan antara kontrasepsi hormonal dan seksualitas merupakan masalah penting dalam perdebatan dan penelitian. Meskipun, saat ini tidak ada rekomendasi untuk menilai perbedaan fungsi seksual sebelum atau selama penggunaan kontrasepsi hormonal, berbagai metode kontrasepsi telah dikaitkan dengan perubahan dalam kesehatan seksual wanita. Kontrasepsi hormonal pada beberapa perempuan memberikan dampak yang berbeda pada permasalahan libido dan gairah seksual. Sedangkan, minat pengguna kontrasepsi hormonal cukup besar dengan penggunaan yang relatif lama tanpa twitching dengan kontrasepsi bukan hormonal.

Berdasarkan data World Health Organization (WHO) tahun 2015 berjumlah 64\% pasangan usia subur di dunia telah menggunakan alat kontrasepsi. Asia Timur merupakan wilayah terbesar dengan angka prevalensi pengguna KB pada tahun 2015 yakni 82\% dari semua negara di dunia (WHO, 2015b). Berdasarkan SDKI tahun 2012 diketahui bahwa alat kontrasepsi yang paling banyak digunakan oleh wanita Indonesia usia 15-49 tahun yang telah menikah adalah KB suntik (31,9\%), pil (13,6\%), IUD $(3,9 \%)$, implan (3,2\%), MOW (3,2\%), dari 33.465 wanita. Secara nasional, pencapaian peserta KB baru (PB) sampai dengan Februari 2015 sebanyak 1.032 .054 peserta, diantaranya peserta suntik $(52,93 \%)$, pil $(24,43 \%)$, implan (8,78\%), IUD (6,97\%), kondom (5,40), MOW (1,41\%), dan MOP $(0,09 \%)$ (BKKBN, 2015). Kemudian terjadi peningkatan pemakaian kontrasepsi (semua cara) dari 62 persen pada SDKI 2012 menjadi 64\% pada SDKI 2017 (BKKBN, 2019). Menurut penelitian Sumini \& Tsalatsa (2015) didapatkan bahwa kontrasepsi suntik sejak tahun 1999 sampai dengan 2012, tetap menduduki peringkat pertama sebagai jenis kontrasepsi yang paling banyak digunakan, baru disusul kontrasepsi pil.

Tingginya pengguna suntik DMPA di berbagai wilayah Indonesia, karena dianggap lebih nyaman dibandingkan dengan alat kontrasepsi dalam rahin (AKDR), mudah diingat dibandingkan pil dan murah. Selain itu pada beberapa pelayanan kesehatan di fasilitas pelayanan primer, ketersediaan metode tersebut sangat mudah didapatkan dibandingkan dengan metode jangka panjang lain seperti implan dan AKDR. Pada beberapa penelitian efek samping dominan dari suntik DMPA adalah perubahan haid, perubahan berat badan dan sakit kepala, dan jarang sekali yang melaporkan adanya perubahan gangguan seksual. Selain kurangnya pemahaman akseptor tentang efek samping yang lain, pada beberapa kultur sosial budaya, relasi seksual merupakan masalah yang sangat tabu di sampaikan secara terbuka, sehingga semakin mengaburkan dampak suntik DMPA pada gairah seksual. Penelitian Kariman, Simbar \& Bahgban (2017) menunjukkan ada perbedaan fungsi seksual antara kelompok DMPA dan oral kontrasepsi, dan gangguan seksual lebih umum terjadi pada akseptor DMPA. Hasil review Espada (2019), menyatakan bahwa penelitian tentang dampak suntik DMPA pada fungsi seksual memberikan hasil yang berbeda beda, sehingga perlu penelitian lanjutan yang lebih banyak.

Masalah seksual dapat menurunkan percaya diri dan kreatifitas seseorang. Hubungan seksual merupakan suatu acuan bagi kualitas hidup khususnya bagi wanita (Ozgoli, Sheikhan, Dolatian, Simbar, Bakhtyari, \& Nasiri, 2015). Seksualitas merupakan dasar dari suatu kehidupan sehingga masalah seksual dapat berdampak buruk bagi kualitas hidup, emosional, dan kebanggaan diri. Diagnostic and Statistical Manual of Mental Disorder IV (DSM-IV) menjabarkan tentang disfungsi seksual sebagai gangguan hasrat seksual yang menyebabkan tekanan berat dan kesulitan untuk berhubungan antar manusia (Zettira \& Nisa, 2015). Beragam faktor pemicu terjadinya gangguan seksual pada wanita, dimulai dari usia, life 
style (merokok, alkohol, free sex), emosional dan penyakit sistemik. Salah satu penyebab terjadinya disfungsi seksual adalah penggunaan kontrasepsi hormonal (Zettira \& Nisa, 2015). Mekanisme kerja DMPA adalah menekan ovulasi. DMPA memberikan efek yang luas terhadap vagina, tetapi belum diketahui secara pasti bagaimana mekanismenya. Beberapa penelitian menunjukkan prevalensi simtom pada vagina yang ditimbulkan oleh hipoestrogenik tidak menunjukkan hasil yang konsisten, hanya satu penelitian menunjukkan bahwa gejala yang muncul sampai dengan $10 \%$ adalah kekeringan pada vagina yang mirip dengan kondisi postmenopause (Hickey, Marino, \& Tachedjian, 2016). Hormon estrogen dan progesteron membawa pengaruh yang berbeda terhadap seksualitas wanita, fungsi jaringan vagina dan sistem saraf pusat yang berperan dalam menentukan pola kegiatan seksual (Ozgoli, Sheikhan, Dolatian, Simbar, Bakhtyari, \& Nasiri, 2015).

Gangguan seksual memiliki dampak besar bagi kualitas hidup perempuan. Banyak perempuan yang tidak menjadikan pengetahuan terkait efek samping kontrasepsi dan hak-hak reproduksinya sebagai dasar dalam memilih metode kontrasepsi sehingga muncullah efek samping yang kedepannya mengganggu kesehatan reproduksi bahkan mempengaruhi kehidupan perempuan secara menyeluruh. Hasil studi pendahuluan yang dilakukan pada bulan Desember 2016, pada 10 akseptor suntik DMPA di PMB S Kota Malang, terkait aktivitas hubungan seksual selama satu bulan terakhir didapatkan hasil yakni sebanyak 7 responden (70\%) mengalami rasa tidak bergairah, 3 responden (30\%) tidak mencapai orgasme, 4 responden $(40 \%)$ merasa berkurangnya lendir pada vagina, 3 responden $(30 \%)$ merasakan nyeri saat berhubungan seksual dan 4 responden $(40 \%)$ merasa tidak puas saat berhubungan seksual.

Setiap perempuan berhak membangun dan merencanakan keluarga tanpa mengurangi hak untuk mendapatkan pelayanan kesehatan seksual dan kesehatan reproduksi yang berkualitas serta didukung oleh data yang menunjukkan bahwa sebagian besar perempuan memilih metode kontrasepsi suntik, maka sangat penting dilakukan penelitian terkait hubungan lama penggunaan kontrasepsi DMPA dengan gangguan seksual ditinjau berdasarkan siklus respon seksual perempuan. Akseptor DMPA diharapkan mampu memberdayakan dirinya untuk membuat keputusan dalam menggunakan kontrasepsi dengan pengetahuan yang cukup tentang kekurangan dan kelebihan pada penggunaan kontrasepsi tersebut. Tujuan dari penelitian ini adalah mengidentifikasi lama penggunaan suntik DMPA, gangguan seksual dan mengnalisis efek lama penggunaan suntik DMPA dengan gangguan seksual.

\section{Metode}

Desain yang digunakan dalam penelitian ini adalah analitik observasional dengan menggunakan pendekatan cross sectional untuk mengetahui hubungan lama pemakaian suntik DMPA dengan ganggan seksual. Pengambilan data dilakukan di PMB "S" Blimbing Kota Malang, pada bulan Februari - April 2017. Populasi dalam penelitian ini adalah semua akseptor DMPA yang berada dalam register pelayanan KB di BPM 'S' pada periode November-Desember tahun 2016 yakni sebanyak 71 akseptor suntik DMPA dengan perhitungan besar sampel menggunakan formula Slovin dengan jumlah sampel 60 orang yang ditetapkan dengan simple random sampling. Kriteria inklusi yang ditetapkan adalah: memiliki kartu akseptor KB, sebagai akseptor $\geq 2$ tahun, paritas $\leq 4$, memiliki pasangan dan melakukan hubungan seksual dalam satu bulan terakhir, tidak sedang menderita penyakit reproduksi seperti infeksi menular seksual, kanker payudara, mioma uteri, kista ovarium dan tidak sedang menyusui.

Teknik pengumpulan data menggunakan data primer dengan instrumen kuesioner FSFI (Female Sexual Function Index) (Rosen, Brown, Heiman, Leiblum, Meston, Shabsigh, Ferguson, \& Jr, 2000), untuk mengidentifikasi disfungsi seksual dengan 6 indikator (lihat tabel 1). Instrumen telah dilakukan uji validitas kepada 30 responden dan masing-masing butir pertanyaan memiliki nilai product moment Pearson $>0,3(\geq 0.3)$ dan uji reliabilitas didapatkan nilai Cronbach's Alpha 0,889 (>0,7), sehingga instrumen layak digunakan. Kategori hasil pengukuran tidak mengalami gangguan seksual, jika 
didapatkan skor $\geq 26,5$ dan jika skor $<26,5$ dikategorikan mengalami gangguan seksual.

Analisis data dimulai dengan menentukan skoring FSFI, yaitu: (1) Skor $\geq 26,5$ dikategorikan tidak mengalami gangguan seksual. Artinya fungsi seksual seorang perempuan dalam batas normal baik dari segi keriteria hasrat, rangsangan, lubrikasi, orgasme, nyeri dan kepuasan dalam berhubungan seksual dan (2) Skor $<26,5$ dikategorikan mengalami gangguan seksual. Artinya terjadi penurunan fungsi seksual seorang wanita dari krtiteria hasrat rangsangan, lubrikasi, orgasme, nyeri dan kepuasan dalam berhubungan seksual. Adapun cara penilaiannya seperti tercantum dalam tabel 1. Data Analisis secara univariat dengan distribusi frekuensi dan bivariat menggunakan uji chi square dengan taraf signifikansi 0.05. Penelitian dilakukan dengan rekomendasi persetujuan etik dari Komisi Etik Penelitian Kesehatan Politeknik Kesehatan Kemenkes Malang dengan Nomor Registrasi: 122/ KEPK-POLKESMA/2017, persetujuan atau izin penelitian di tempat penelitian, dan informed consent dari responden.

Tabel 1. Skor Penilaian FSFI.

\begin{tabular}{lllllll}
\hline Domain & Pertanyaan & Rentang Skor & Faktor PengaliSkor min & Skor max & Skor \\
\hline Hasrat seksual & 1,2 & $1-5$ & 0,6 & 1,2 & 6 & \\
Gairahseksual & $3,4,5,6$ & $0-5$ & 0,3 & 0 & 6 & Hasil skor \\
Lubrikasi vagina & $7,8,9,10$ & $0-5$ & 0,3 & 0 & 6 & pengisian \\
Orgasme & $11,12,13$ & $0-5$ & 0,4 & 0 & 6 & responden \\
Kepuasan & $14,15,16$ & $0-5$ & 0,4 & 0 & 6 & \\
Kesakitan & $17,18,19$ & $0-5$ & 0,4 & 0 & 6 & 6
\end{tabular}

(Sumber: Rosen, Brown, Heiman, Leiblum, Meston, Shabsigh, Ferguson, \& Jr, 2000)

\section{Hasil}

\section{Karakteristik responden dan gangguan seksual}

Tabel 2 menjelaskan bahwa setengah $(50,0 \%)$ dari 60 responden berusia $>30$ tahun dan sebagian besar $(60 \%)$ tidak bekerja. Selain itu, dijelaskan bahwa sebagian besar responden dengan status multipara $(56,7 \%)$ dan lama pernikahan $\leq 9$ tahun. Tabel 3 menunjukkan responden gangguan seksual terjadi pada responden yang berumur $>30$ tahun sejumlah $77,8 \%$, pada bekerja $79,4 \%$, paritas multipara $79,4 \%$, dan lama pernikahan $>9$ tahun berjumlah $89,3 \%$.

Tabel 2. Karakteristik responden berdasarkan umur, pekerjaan, paritas dan lama pernikahan

\begin{tabular}{lll}
\hline Karakteristik & $\boldsymbol{f ( \mathbf { n } = \mathbf { 6 0 } )}$ & $\mathbf{\%}(\mathbf{n}=\mathbf{1 0 0})$ \\
\hline Umur 30, 50 $(27,00-37,75)^{*}$ & & \\
$\quad \leq 30$ tahun & 30 & 50,0 \\
$\quad>30$ tahun & 30 & 50,0 \\
Pekerjaan & & \\
$\quad$ Tidak bekerja & 36 & 60,0 \\
$\quad$ Bekerja & 24 & 40,0 \\
Paritas $(1,00-2,00)^{*}$ & & \\
$\quad$ Primipara & 26 & 43.3 \\
$\quad$ Multipara & 34 & 56.7 \\
Lama Pernikahan $9,00(5,25-15,00)^{*}$ & & \\
$\quad \leq 9$ tahun & 32 & 53.3 \\
$\quad>9$ tahun & 28 & 46,7 \\
\hline
\end{tabular}




\section{Lama Penggunaan dan Gangguan Seksual}

Hasil analisis pada tabel 4 dapat dijelaskan bahwa dari 60 responden dengan lama penggunaan 2$\leq 3$ tahun, $17 \%$ mengalami gangguan seksual dan pada penggunaan $\geq 5$ tahun, $100 \%$ mengalami gangguan seksual. Hasil uji statistik dengan chi square menunjukkan ada hubungan antara lama penggunaan suntik DMPA dengan gangguan seksual $(\mathrm{p}=0.038)$.

Tabel 3. Karakteristik akseptor DMPA dan gangguan seksual

\begin{tabular}{|c|c|c|c|}
\hline \multirow{3}{*}{ Karakteristik responden } & \multicolumn{2}{|c|}{ Gangguan seksual } & \multirow{3}{*}{$\begin{array}{l}\text { Jumlah } \\
f(\%)\end{array}$} \\
\hline & Ada gangguan & Tidak ada gangguan & \\
\hline & $f(\%)$ & $f(\%)$ & \\
\hline \multicolumn{4}{|l|}{ Umur } \\
\hline$\leq 30$ tahun & $20(66,7)$ & $10(33,3)$ & $30(100)$ \\
\hline$>30$ tahun & $25(83,3)$ & $5(16,7)$ & $30(100)$ \\
\hline Jumlah & $45(75,0)$ & $15(25,0)$ & $60(100)$ \\
\hline \multicolumn{4}{|l|}{ Pekerjaan } \\
\hline Bekerja & $28(77,8)$ & $8(22,2)$ & $36(100)$ \\
\hline Tidak bekerja & $17(70,8)$ & $7(29,2)$ & $24(100)$ \\
\hline Jumlah & $45(75,0)$ & $15(25,0)$ & $60(100)$ \\
\hline \multicolumn{4}{|l|}{ Paritas } \\
\hline Primi & $18(69,2)$ & $8(30,8)$ & $26(100)$ \\
\hline Multi & $27(79,4)$ & $7(20,6)$ & $34(100)$ \\
\hline Jumlah & $45(75,0)$ & $15(25,0)$ & $60(100)$ \\
\hline \multicolumn{4}{|l|}{ Lama Pernikahan } \\
\hline$\leq 9$ tahun & $20(60,6)$ & $12(36,4)$ & $33(100)$ \\
\hline$>9$ tahun & $25(89,3)$ & $3(10,7)$ & $28(100)$ \\
\hline Jumlah & $45(75,0)$ & $15(25,0)$ & $60(100)$ \\
\hline
\end{tabular}

Tabel 4. Hubungan lama penggunaan kontrasepsi dengan gangguan seksual

\begin{tabular}{llllllll}
\hline \multirow{2}{*}{ Lama penggunaan } & \multicolumn{2}{l}{ Tidak ada gangguan } & \multicolumn{2}{l}{ Ada gangguan } & \multicolumn{2}{l}{ Total } & \multirow{2}{*}{$\boldsymbol{P}$-value } \\
\cline { 2 - 7 } & $\boldsymbol{f}$ & $\mathbf{\%}$ & $\boldsymbol{f}$ & $\mathbf{\%}$ & $\boldsymbol{f}$ & $\mathbf{\%}$ & \\
\hline $2-<3$ tahun & 10 & 83 & 2 & 17 & 12 & 100 \\
$3-<4$ tahun & 4 & 36 & 7 & 64 & 11 & 100 & 0,038 \\
$4-<5$ tahun & 1 & 9 & 10 & 91 & 11 & 100 & 100 \\
$\geq 5$ tahun & 0 & 0 & 26 & 100 & 26 & 100 \\
\hline Jumlah & 15 & 25 & 45 & 75 & 75 & & \\
\hline
\end{tabular}

\section{Pembahasan}

Penyebab gangguan seksual pada perempuan dijelaskan oleh Coelho \& Barros (2019) merupakan multifaktor, termasuk didalamnya adalah masalah psikologis, seperti: depresi, konflik hubungan, stress, adanya riwayat pelecehan fisik atau seksual, dan penggunaan obat obatan. Sedangkan, pada permasalahan fisik adalah endometriosis atau gangguan pada geniourinaria. Beberapa fungsi seksual perempuan dipengaruhi oleh faktor fisk, biologis dan psikologis yang berkaitan antara satu dengan yang lain.

Pada karakteristik faktor umur, paritas, pekerjaan dan lama pernikahan dapat mempengaruhi adanya gangguan seksual. Pengaruh umur sangat tergantung pada perubahan sistem endokrin yang diatur oleh sistem saraf pusat yang salah satunya akan mempengaruhi perilaku seksual. Dalam penelitian ini, gangguan seksual banyak dialami oleh pengguna DMPA dengan umur $>30$ tahun $(55,6 \%)$. Faktor paritas juga dapat mempengaruhi seksualitas wanita. Dalam penelitian ini akseptor multipara (60\%) cenderung mengalami gangguan seksual jika dibandingkan primipara (40\%). Riwayat persalinan, khususnya persalinan pervaginam lebih berpotensi untuk terjadi kerusakan pada dasar panggul, terutama pada kasus persalinan operatif pervaginan (vakum ekstraksi), kala II lama, bayi besar dan laserasi 
perinium. Penelitian yang dilakukan oleh Gommesen, Nohr, Qvist, \& Rasch (2017), pada persalinan pervaginam primipara sejumlah 181 tanpa robekan perinium dan dan 189 dengan robekan perinium yang dilakukan pengamatan 12 bulan kemudian, didapatkan bahawa pada robekan derajad 2 berisiko terjadi dispareneu dan derajad 3 serta 4 lebih dari 50\% mengalami dispareneu.

Kesibukan wanita dapat mempengaruhi kehidupan seksualnya. Hal ini berkaitan dengan tingkat depresi terhadap beban kerja. Studi yang dilakukan pada 100 wanita di India didapatkan hasil bahwa wanita yang bekerja memiliki tingkat stres yang lebih tinggi dibandingkan wanita yang tidak bekerja (Shukla, Jaiswal, Agrahari \& Shingh, 2017), sehingga disimpulkan bahwa wanita yang bekerja berpotensi mengalami gangguan seksual jika dibandingkan dengan ibu rumah tangga. Hasil penelitian Dibaji, Oreyzi, \& Abedi (2017), pada 94 ibu rumah tangga dan 94 perempuan bekerja, menunjukan bahwa pada kedua kelompok tersebut tidak ada perbedaan dalam hal stress dan tuntutan emosional dalam mengelola rumah tangga, terutama peran keluarga. Hal ini menunjukkan bahwa perempuan yang bekerja sebagai ibu rumah tangga juga rentan stress dalam menjalankan perannya dikeluarga, dan bisa menimbulkan gangguan seksual.

Salah satu asumsi umum yang beredar di ranah publik adalah faktor lama pernikahan mempengaruhi performa dan daya tarik seksual. Beberapa studi menunjukkan terjadinya penurunan gairah secara bertahap mengakibatkan gangguan seksual pada suatu pernikahan. Hasil penelitian menunjukkan pengguna kontrasepsi DMPA dengan lama pernikahan $>9$ tahun mayoritas mengalami gangguan seksual yakni sebanyak 55,6\%. Penelitian yang telah dilakukan oleh Stroope dkk. tentang hubungan lama pernikahan dengan aktivitas seksual pada 1.656 menunjukkan bahwa frekuensi aktivitas seksual jika dibandingkan dengan lama pernikahan memiliki pola huruf U. Hal tersebut dapat diartikan bahwa pada awal masa pernikahan aktivitas seksual begitu intens, kemudian mengalami stagnan dan penurunan pada tengah-tengah masa pernikahan dan pada akhirnya setelah usia pernikahan hampir 50 tahun kehidupan seksual kembali mencapai puncaknya. Pengamatan longitudinal ini menegaskan bahwa terjadi penurunan hasrat seksual namun dikarenakan pasangan sudah terbiasa memiliki satu sama lain maka cenderung mengabaikan gangguan seksual yang dialami seiring bertambahnya usia pernikahan (Stroope, McFarland \& Uecker, 2015a).

Hasil penelitian ini menunjukkan gangguan seksual pada akseptor suntik DMPA sudah mulai terjadi pada pemakaian 2 sampai $<3$ tahun walaupun dengan angka yang masih relatif rendah $(17 \%)$, namun semakin lama pemakaian kontrasepsi sudah mulai ada peningkatanya akan keluhan tersebut dan pada akseptor suntik DMPA $\geq 5$ tahun seluruhnya mengalami gangguan seksual. Hasil penelitian ini menunjukkan lama penggunaan kontrasepsi DMPA $\geq 5$ tahun, semua responden mengalami adanya gangguan seksual dari berbagai aspek yakni hasrat, gairah, orgasme, lubrikasi, kepuasan, dan nyeri saat berhubungan seksual.

Lama penggunaan akan mempengaruhi kadar estradiol serum sehingga dapat lebih rendah pada fase folikuler dini. Hormon estrogen merupakan hormon seksual wanita yang membawa sifat-sifat wanita baik pada organ reproduksi maupun mental. Dengan demikian, hormon tersebut membawa insting kewanitaan, misalnya tingkat rasa malu, sensitifitas, gairah seksual dan penampilannya. Efek terhadap organ reproduksi khususnya genetalia adalah menambah jumlah kelenjar pada labia ketika wanita mencapai orgasme. DMPA mengandung progestogen sehingga dalam penggunaan jangka panjang mampu memberikan feedback negatif terhadap produksi estrogen yang penting bagi kesehatan organ reproduksi wanita dan seksualitas. Affandi (2014) menyatakan bahwa penggunaan DMPA jangka panjang ( $\geq 2$ tahun) beresiko besar terhadap rendahnya kadar estradiol serum yang dapat berupa kehilangan massa tulang, amenorea berkepanjangan, kekeringan pada vagina sampai penurunan libido. Kondisi hipoestrogen berdampak pada fungsi seksual: pengurangan pelumasan pada vulva vagina, vasokongesti saat berhubungan seksual, dan dispareunia (Coelho \& Barros, 2019). 
Rendahnya kadar estrogen dalam tubuh menimbulkan beberapa masalah seksual, salah satu masalah seksual yang terjadi pada responden adalah timbulnya nyeri saat berhubungan seksual dan berkurangnya dorongan untuk melakukan hubungan seksual. Hal ini didukung pendapat Ozgoli, Sheikhan, Dolatian, Simbar, Bakhtyari, \& Nasiri (2015), yang menyatakan bahwa pengguna DMPA cenderung mengalami masalah seksual pada aspek dorongan seksual $(\mathrm{p}=0.018)$ dan nyeri saat berhubungan seksual $(\mathrm{p}=0.002)$. Pada penelitian Kariman, Simbar, \& Bahgban (2017) dengan taraf signifikansi 0.05 menunjukkan bahwa injeksi DMPA memberikan dampak pada gairah seksual (0.01), lubrikasi (0.01) dan nyeri saat berhubungan seksual (0.02), sedangkan pada Peneliti Lubis, Aufa, Lutan, Siregar, Edianto, Effendi, \& Marpaung (2018) didapatkan ada perbedaan fungsi seksual pada akseptor DMPA dan cyclofem dengan indikator FSFI didapatkan hasrat seksual $(p=0.02)$, lubrikasi $(p=0.01)$ dan nyeri $(\mathrm{p}=0.01)$.

Kariman, Simbar, \& Bahgban (2017), menyatakan keseimbangan hormonal mempengaruhi keberlangsungan fungsi seksual. Estradiol memiliki dampak yang besar pada ephitelial vagina dan lubrikasi. Penurunan kadar estrogen dapat mengurangi suplai darah ke daerah vagina, berkurangnya lubrikasi dan menyebabkan nyeri saat berhubungan seksual. Menurut Lunsen dan Laan yang dikutip oleh Ozgoli, Sheikhan, Dolatian, Simbar, Bakhtyari, \& Nasiri (2015) menyatakan bahwa keseimbangan hormon diperlukan untuk memulai dan melanjutkan fungsi seksual. Estradiol, nitric oxide, dan polypeptide memiliki efek penting pada epithelium dan pelumasan vagina, dan estrogen memiliki peran utama dalam efektivitas faktor-faktor ini. Tingkat estradiol yang mencukupi diperlukan untuk mempertahankan pelumasan vagina dan mencegah dyspareunia.

Ada beberapa pendekatan yang dibutuhkan ketika membahas tentang fungsi seksual perempuan karena banyak faktor yang mempengaruhinya (Espada, Alarcón, Iglesia-Larrad, Bote-Bonaechea, \& Montejo, 2019). Secara komprehensif faktor biologis, psikologis, interpersonal, dan sosiokultural semuanya dapat mempengaruhi fungsi seksual perempuan, dan faktor-faktor ini berinteraksi satu sama lain dalam sistem yang dinamis dari waktu ke waktu. Faktor biologis termasuk perubahan hormon yang mempengaruhi libido atau masalah medis atau anatomi yang mempengaruhi respon seksual. Faktor psikologis termasuk gejala suasana hati, seperti depresi atau kecemasan. Beberapa contoh interpersonal faktor termasuk kepuasan umum dalam hubungan wanita dengan pasangannya, yang terkait erat untuk kepuasan seksual secara keseluruhan, serta kualitas komunikasi dalam hubungan, sehingga beberapa faktor sosial budaya yang perlu dipertimbangkan termasuk sikap tentang seks.

Sebagian besar pengguna kontrasepsi DMPA tidak mengetahui bahwa gangguan seksual merupakan salah satu efek samping dari penggunaan kontrasepsi DMPA dalam jangka panjang. Berdasarkan informasi dari responden, didapatkan bahwa keluhan seksual sudah dirasakan oleh mereka, namun banyak yang menganggap bahwa masalah seksual merupakan hal pribadi yang tabu untuk diceritakan ke orang lain. Sehingga, perasaaan dan rasa selama ini terhadap kehidupan seksual yang dialami bukan menjadi gangguan atau hal yang biasa sebagai seorang perempuan. Perlunya penelitian lanjutan dengan melakukan analisis faktor lain, seperti riwayat persalinan dan faktor keharmonisan dengan pasangan yang juga bisa mempengaruhi gangguan seksual.

\section{Simpulan}

Lama penggunaan kontrasepsi suntik DMPA meningkatkan kejadian gangguan seksual pada akseptor. Semua akseptor suntik DMPA mengalami gangguan seksual bila lama penggunaaan $\geq 5$ tahun, antara lain hasrat, gairah, orgasme, lubrikasi, kepuasan, dan nyeri saat berhubungan seksual. Informasi yang kurang tentang efek samping dan pilihan atau kecocokan memungkinkan akseptor menggunakan suntik DMPA dalam jangka waktu lama. Solusi yang dapat diberikan pada pengguna kontrasepsi DMPA dapat melakukan metode switching, yang bergantian menggunakan kontrasepsi hormonal dan non-hormonal, sehingga memungkinkan terjadi efek samping dapat minimal. 


\section{Ucapan terima kasih}

Peneliti mengucapkan banyak terima kasih kepada Kepala PMB Sumidjah Ipung di Plaosan Blimbing Kota Malang atas bantuannya pada proses penelitian yang telah dilakukan.

\section{Referensi}

Affandi, B. (2014). Buku panduan praktis pelayanan kontrasepsi. Jakarta: PT. Bina Pustaka Sarwono Prawirohardjo

BKKBN. (2015). Laporan umpan balik: Hasil pelaksanaan subsistem pencatatan dan pelaporan. https://www.bkkbn.go.id/po-content/uploads/Final_lakip_bkkbn_2016.pdf

BKKBN. (2019). BKKBN tingkatkan jumlah kepersertaan KB dan kesadaran masyarakat akan kesehatan reproduksi melalui kegiatan bakti sosial dalam rangka peringatan HARGANAS 2019. https://www.bkkbn.go.id/

Coelho, F. de C., \& Barros, C. (2019). The potential of hormonal contraception to influence female sexuality. International Journal of Reproductive Medicine, 2019, 9701384. https://doi.org/10.1155/2019/9701384

Dibaji, S. M., Oreyzi, S. H. R., \& Abedi, M. R. (2017). Occupation or home: comparison housewives and working women in the variables of stress, depression and perception of quantitative, mental and emotional home demands. Review of European Studies, 9(2). 268-274. https://doi.org/10.5539/res.v9n2p268

Espada, N. M. C., Alarcón, R. de, Iglesia-Larrad, J. I. de la, Bote-Bonaechea, B., \& Montejo, Á. L. (2019). Hormonal contraceptives, female sexual dysfunction, and managing strategies: A review. J. Clin. Med, 8(908), 1-22. https://doi.org/10.3390/jcm8060908

Gommesen, D., Nohr, E., Qvist, N., \& Rasch, V. (2019). Obstetric perineal tears, sexual function and dyspareunia among primiparous women 12 months postpartum: A Prospective cohort study. BMJ Open, 9(12), 1-9. https://doi.org/10.1136/bmjopen-2019-032368

Hickey, M., Marino, J. L., \& Tachedjian, G. (2016). Mechanisms of HIV transmission in depo-provera users: The likely role of hypoestrogenism. $J$ Acquir Immune Defic Syndr, 71(1). 1-7. https://doi.org/10.1097/QAI.0000000000000805

Kariman, N., Z, Z. S., Simbar, M., A, A. Z., \& Bahgban, A. A. (2017). Sexual dysfunction in two types of hormonal contraception: combined oral contraceptives versus depot medroxyprogesterone acetate. Journal of Midwifery Reproductive Health, 5(1), 806-813. https://doi.org/10.22038/jmrh.2016.7763

Lubis, Aufa, Q., Lutan, D., Siregar, M. F. G., Edianto, D., Effendi, I. H., \& Marpaung, J. (2018). Female sexual function in DMPA and cyclofem. IOSR Journal of Dental and Medical Science, 17(10), 76-81. https://doi.org/10.9790/0853-1710067681

Ozgoli, G., Sheikhan, Z., Dolatian, M., Simbar, M., Bakhtyari, M., \& Nasiri, M. (2015). Comparison of sexual dysfunction in women using depo-Medroxyprogesterone acetate (DMPA) and cyclofem. Journal of Reproduction and Infertility, 16(2), 90-95.

Rosen, R., Brown, C., Heiman, J., Leiblum, S., Meston, C., Shabsigh, R., Ferguson, D., \& Jr, R. D. (2000). The Female Sexual Function Index (FSFI) : A Multidimensional self-report instrument for the assessment of female sexual function. $J$ Sex Marital Ther, 26(2), 191-208. https://doi.org/10.1080/009262300278597

Saifudin, A. B., Affandi, B., Baharudin, M., \& Sukir, S. (2014). Buku panduan praktis pelayanan kontrasepsi. PT. Bina Pustaka Sarwono Prawirohardjo

Shukla, S., Jaiswal, M., Agrahari, K., \& Shingh, A. (2017). A Study on stress level among working and nonworking women. International Journal of Home Science, 3(1), 349-357

Stroope, S., McFarland, M. J., \& Uecker, J. E. (2015b). Marital characteristics and the sexual relationships of u.s. older adults: an analysis of national social life, health, and aging project data. University of Texas Population Research Center, 44(1), 233-247. https://doi.org/10.1007/s10508-014-0379-y

Sumini, \& Tsalatsa, Y. (2015). Tren pemakaian kontrasepsi di Indonesia 1999-2012. Populasi, 23(1), 35-49. https://doi.org/10.22146/jp.8562 
Gangguan Seksual pada Akseptor Suntik Depo Medroxyprogesteron Asetat

Tarsikah, Wahyu Setyaningsih, Yusniyah Abdillah

Jurnal Kesehatan Metro Sai Wawai. Vol 13, No 1, Juni 2020

WHO. (2015). World contraceptive patterns 2015. Retreived from: https://www.un.org/en/development/desa/population/publications/pdf/family/Infochart-World Contraceptive-Patterns-2015.pdf

Zettira, Z., \& Nisa, K. (2015). Analisis hubungan penggunaan kontrasepsi hormonal dengan disfungsi seksual pada wanita. Majority, 4(7), 103-107

Sitasi: Tarsikah, Setyaningsih, W. \& Abdillah, Y. (2020). Gangguan Seksual pada Akseptor Suntik Depo Medroxiprogesteron Asetat (DMPA). Jurnal Kesehatan Metro Sai Wawai. 13(1). 11-19. DOI: $10.26630 / \mathrm{jkm} . \mathrm{v} 13 \mathrm{i} 1.1971$

Hiperlink DOI: http://dx.doi.org/10.26630/jkm.v13i1.1971 